\title{
The influence of company's external and internal factors to financial performance and company competitiveness on consumer good companies industry
}

\author{
Ahmad Nur Budi Utama; Syamsurijal Tan; Tona Aurora Lubis*; \\ Asep Machpuddin
}

Faculty of Economics and Business, Universitas Jambi, Indonesia

*To whom correspondence should be addressed. Email: tonalubis@ unja.ac.id

\begin{tabular}{|l|l|l|l|l|}
\hline DOI: & Received: & Revised: & Accepted: & Published: \\
10.22437/ppd.v8i4.10703 & 15.10 .2020 & 05.11 .2020 & 06.11 .2020 & 07.11 .2020 \\
\hline
\end{tabular}

\begin{abstract}
The purpose of this study is to predict the influence model of external and internal factors of a company, starting a company's financial performance on the competitiveness of companies in the Consumer Goods Industry Sector on the Indonesia Stock Exchange. The sample of this research is 35 companies in the Consumer Goods Industry Sector on the Indonesia Stock Exchange during the period of 2016 to 2018. This research is used SEM (Structural Equation Modeling) based on component or variance based analysis known as Partial Least Square (PLS). The results of this study concluded that external factors affect the company's financial performance and company competitiveness. Internal factors also affect the company's financial performance and competitiveness but the influence of both external factors and internal factors respectively are not able to mediate the financial performance of the company's competitiveness
\end{abstract}

Keywords: Company competitiveness, External factor, Financial performance, Internal factor

JEL Classification: G11, G23

\section{INTRODUCTION}

Indonesia's Global Competitiveness Index in 2018 is in the $45^{\text {th }}$ rank out of 140 countries. This ranking was released by the World Economic Forum (WEF) in 2018. The WEF states that the competitiveness index is compiled annually to determine the global competitiveness landscape, in line with the fourth industrial revolution or industry 4.0.

Competitiveness according to WEF benchmarks was identified to 5 (five) dominant factors. On the macro side there are 3 (three) factors, namely: (a) the macro economic conditions are not conducive; (b) the poor quality of public institutions in carrying out their functions as facilitators and service centers; and (c) weak technology development policies in facilitating the need for increased productivity. Meanwhile, at the micro or business level, 2 (two) prominent factors are: (a) low business efficiency at the level of company operations; and (b) the weak business competition climate. 
The term comparative advantage was originally put forward by David Ricardo in 1817 when discussing trade between two countries. According to Ricardo the theory of absolute superiority becomes the theory of comparative advantage. This theory explains that trade occurs when there are differences in comparative advantage. Comparative advantage will be achieved if a country is able to produce goods and services more at a lower cost than other countries.

Another competitiveness theory is superior competitiveness according to Porter (1980), Porter's theory of competitiveness departs from his belief that classical economics that explains comparative advantage is inadequate or even incorrect. According to Porter, a country gains a competitive advantage if the company (which is in the country) is competitive. A country's competitiveness is determined by the ability of industries to innovate and improve their capabilities. Hamel \& Prahalad (1995) suggests that companhamies build competitive strategies around the core of shared competencies and be able to have good company performance in the preparation of competitiveness strategies.

Companies that do not have competitive advantage will surely be abandoned by the market. Because not having competitiveness means the company has no advantage, and not superior means it is difficult for the company to stay in the market for the long term. Competitiveness is related to how effective an organization is in the competitive market, compared to other organizations that offer the same or similar products or services. Companies that are able to produce quality products or services and good performance are companies that have the power to be able to compete.

One area that is very potential to develop is the Consumer Goods Industry sector. Consumption goods consisting of daily needs and other complementary goods become very potential to be developed. The Consumer Goods Industry Sector is one of the Industrial sectors in the Indonesia Stock Exchange (IDX) that continues to grow and develop.

The Consumer Goods Industry on the Indonesia Stock Exchange consists of 5 subsectors, namely the Food and Beverage Sub-Sector, the Cigarette Sub-Sector, the Pharmaceutical Sub-Sector, the Cosmetics and Household Goods Sub-Sector, and the Household Equipment Sub-Sector.Based on the increasing consumption needs, it is predicted that this industrial sector will continue to increase until the following years. It also demands that companies in the consumer goods sector must have good and competitive company performance in order to survive in increasingly fierce business competition.

Competitiveness in the context of financial management has several indicators. According to Saedi, Sofian, Rasid, Saeid, (2012), the company's competitiveness can be seen from the company's growth as measured by asset growth. On research of Zhaohua, Yaobin, Kwok \& Jinlong (2010), and the research of Liang, Zhang, \& Cui (2015) which suggests to measure competitiveness can be based on sales growth. According to Morgan \& Hunt (2004), the company's competitiveness can be seen from the company's market share and the company's market performance.

Research on the effect of company performance on competitiveness in several countries has been carried out. Among them Hsiao, Lin, Xiang-Ying, His-Peng, \& Hueiju (2010), examine that the company's performance can have an influence on the company's competitiveness. Teeratansirikool, Siengthai, Badir, \& Charoenngam (2013) stated that 
the company's financial performance has an influence on the competitiveness of the company itself in the market.

On the other hand, several studies on the influence of external factors and company internal factors in several countries on competitiveness have also been carried out. Khan, Khan, Rukh \& Imdadullah (2012) found that the company's external factors such as interest rates and inflation did not significantly influence the company's competitiveness as reflected by the return of the KSE 100 index shares, while the external factors in the form of the exchange rate had a significant effect on the competitiveness of the company as reflected by the return of the KSE 100 index shares. Research Prempeh (2016) examines external factors in the form of macro variables that are reflected by inflation and interest rates do not affect the competitiveness of companies which is reflected by stock price volatility.

Instead, He, Shen, Li, Xu, Zhao, \& Long (2017) suggesting that the company's internal and external factors can influence and impact on the company's financial performance activities. The company's external factors according to research. He et al. (2018) namely Government Pressure (GP) in the form of government regulations, Social Pressure (SP) in the form of environmental protection and responsibility around companies operating, Economic Pressure (EP) such as exports, domestic currency exchange rates, foreign exchange, inflation and interest rates .

Sheikh, Wang, \& Khan (2013) conduct research on internal factors projected by the number of directors and employees on the company's financial performance projected by Return on Assets (ROA), Return on Equity (ROE), Tobins Q, and Return on Investment (ROI). This research concluded that there is an influence of the company's internal factors on the company's financial performance.

Research of Rivera, Munoz \& Moneva (2017) examine that a company's internal factors can affect the performance of the company. The company's external factors are social responsibility, shareholders, inflation, and interest rates. Financial performance are Return on Equity (ROE), Return on Sales (ROS), and Tobins'Q.

Based on previous exposure about the phenomenon and research gap, this study aims to predict the influence of company's external and internal factors to financial performance and company competitiveness on consumer good companies industry.

\section{METHODS}

The number of samples in this study were 35 companies. The sample was determined using the purposive sampling method of judgment sampling type. The sample selection criteria are based on the considerations: 1) The research period in this study is from 2016 to 2018, which is listed on the Indonesia Stock Exchange; 2) Companies in the consumer goods industry sub-sector that have complete financial statements during the study period.

To predict the influence of company's external and internal factors to financial performance and company competitiveness, the Structural Equation Modeling (SEM) based on component or variance which is well known as Partial Least Square (PLS), is used. The preliminary research model is shown in Figure 1. 


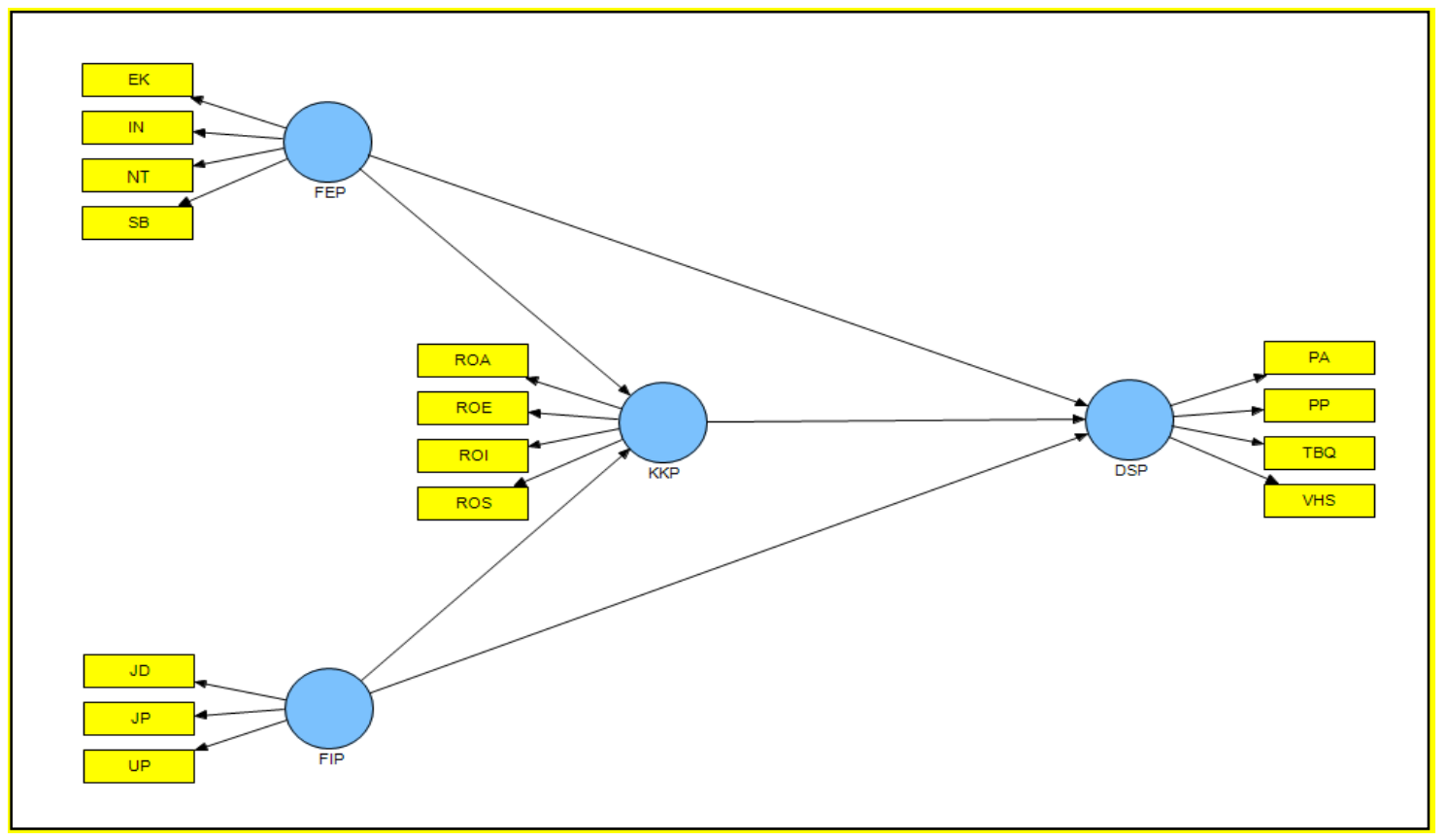

Figure 1. Preliminary research model

The measurement and assessment of variables and indicators in the study are given as Tabel 1 .

Table 1. Operational variables

\begin{tabular}{|c|c|c|}
\hline Variable & Indicator & Formula \\
\hline \multirow{7}{*}{$\begin{array}{l}\text { Corporate } \\
\text { Competitiveness } \\
\text { (DSP) }\end{array}$} & Stock Price Volatility & Standard deviation of the company's stock price \\
\hline & \multirow[t]{2}{*}{ Asset growth } & Total Aktiva Th $i-$ Total Aktiva Th $i-1$ \\
\hline & & Total Aktiva Tahun $i-1$ \\
\hline & Sales Growth & Total Sales Th $i-$ Total Sales Th $i-1$ \\
\hline & & Total Sales Th $i-1$ \\
\hline & \multirow[t]{2}{*}{ Tobins -Q } & Total Market Value + Total Book Value \\
\hline & & Total Book Value of Asset \\
\hline \multirow{8}{*}{$\begin{array}{l}\text { Financial } \\
\text { Performance } \\
\text { Company (KKP) }\end{array}$} & \multirow[t]{2}{*}{ Return on Equity } & Net Income $_{t}$ \\
\hline & & Equity $_{t}$ \\
\hline & \multirow[t]{2}{*}{ Return on Sales } & profit before tax and interest \\
\hline & & Sales \\
\hline & \multirow{2}{*}{ ROI } & Total Sales - Investation \\
\hline & & Investation $x 100 \%$ \\
\hline & \multirow{2}{*}{$R O A$} & Net Income \\
\hline & & $R U A=\overline{\text { Total Aset }}$ \\
\hline \multirow{4}{*}{$\begin{array}{l}\text { External Company } \\
\text { Factors (FEP) }\end{array}$} & Export & Number of company exports in one period. \\
\hline & Exchange rate & The ratio of the value of the rupiah to the dollar. \\
\hline & Inflation & Changes in the average price of goods and services \\
\hline & Interest rate & The value of interest rates that are visited in each time period \\
\hline \multirow{3}{*}{$\begin{array}{l}\text { Internal Company } \\
\text { Factors (FIP) }\end{array}$} & Number of Directors & $\mathrm{JM}=$ total of direction in companya \\
\hline & Number of Employees & $\mathrm{JE}=$ total of employees in company \\
\hline & Company Size & $\mathrm{UP}=$ total assets \\
\hline
\end{tabular}




\section{RESULTS AND DISCUSSION}

Before conducting the analysis, an evaluation of the model was carried out first, wich was related to the loading factor (outer loading). According to Ghozali (2008) convergent validity of the measurement model with reflective indicators can be seen from the correlation between item scores / indicators and their construct scores. This correlation is known as the loading factor (outer loading). Indicators are considered reliable if they have a positive correlation value above 0.70 . However, at the scale development research stage, loading 0.5 to 0.6 is still acceptable.

Based on the guidance, it appears that in some variables there are indicators that have a loading factor value $<0.5$, ie the FEP variable is an IN (inflation), NT (exchange rate) and SB (interest rate), the KKP variable is the ROI (Return On Investment), the DSP variable is the PA (Asset Growth) and, TBQ (Tobin's Q). These six indicators are then exclude from the model.

After removing the indicators, a modified SEM-PLS model is constructed as shown in Figure 2.

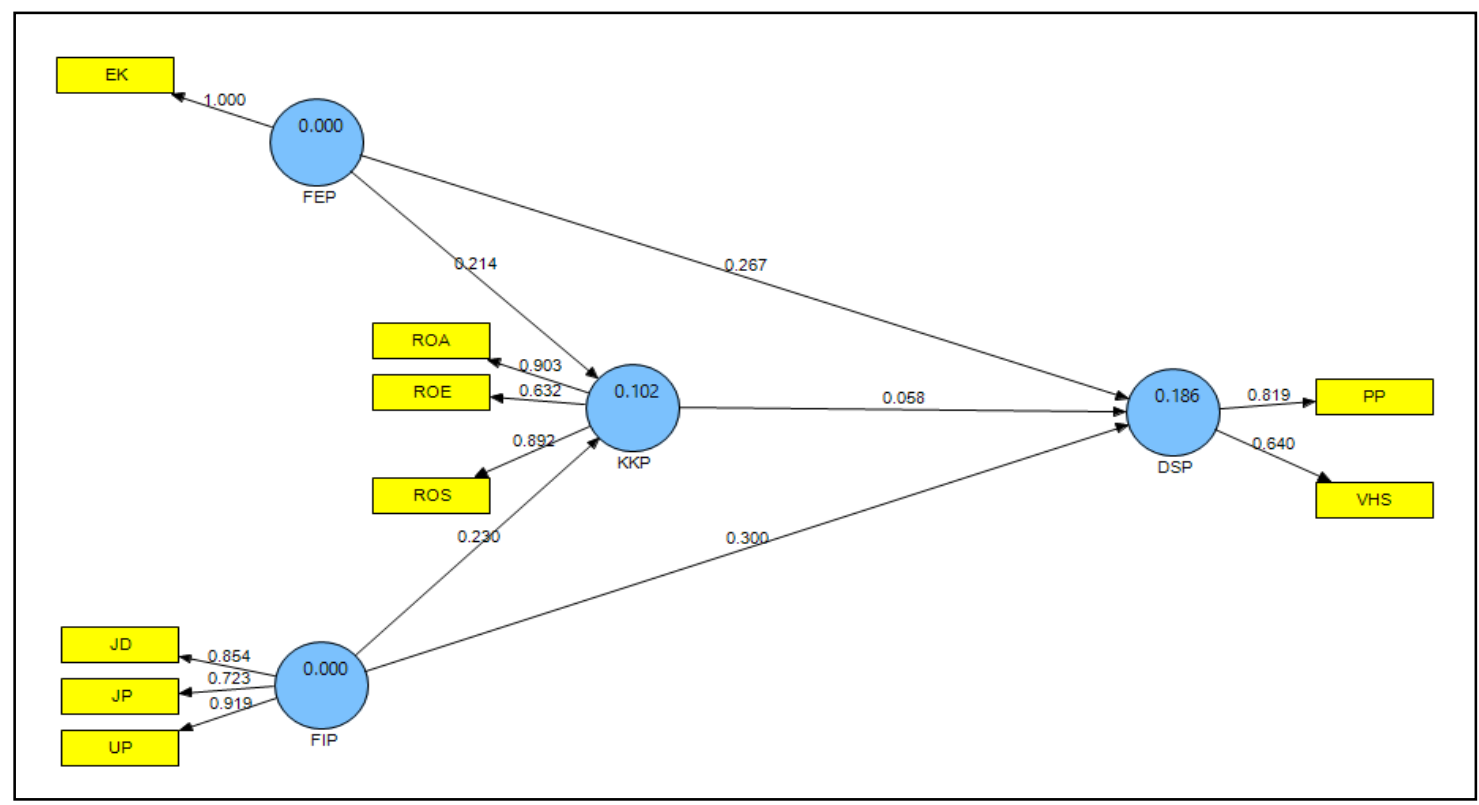

Figure 2. A modified model

Convergent validity from testing the indicator (measurement model) can not only be seen from the value of the loading factor but can also be seen from the results of the calculation of the modified model in the form of Average Variance Extracted and Composite Reliability. The Table 2 is Average Variance Extracted and Composite Reliability.

Table 2. AVE and composite reliability

\begin{tabular}{cccc}
\hline Variable & $\begin{array}{c}\text { Average Variance Extracted } \\
\text { (AVE) }\end{array}$ & $\begin{array}{c}\text { Composite } \\
\text { Reliability }\end{array}$ & Information \\
\hline DSP & 0.540310 & 0.698394 & Qualified \\
FEP & 1.000000 & 1.000000 & Qualified \\
FIP & 0.698433 & 0.873126 & Qualified \\
KKP & 0.669817 & 0.855988 & Qualified \\
\hline
\end{tabular}

Based on the loading factor value, Average Variance Extracted and Composite Reliability, the indicators of each variable are reliable and valid reflecting their respective 
variables.

Testing the structural model's goodness of fit against the inner model using predictive-relevance $(\mathrm{Q} 2)$ values. Magnitude Q2 has a range value of $0<\mathrm{Q} 2<1$. The closer to 1 means the better the model (Solimun, 2011). The result of predictive-relevance value calculation is 0.268593 or $26.86 \%$ shows that the diversity of data that can be explained by the model is $26.86 \%$. These results indicate that the value of Q Square> 0 gives the meaning that this research model has predictive-relevance and can be used for hypothesis testing.

The influence between variables is shown through coefficient and significance of t statistic as shown in Table 3.

Table 3. The modified model hypothesis testing

\begin{tabular}{cccccc}
\hline & $\begin{array}{c}\text { Original } \\
\text { Sample (O) }\end{array}$ & $\begin{array}{c}\text { Sample } \\
\text { Mean (M) }\end{array}$ & $\begin{array}{c}\text { Standard } \\
\text { Deviation } \\
(\text { STDEV })\end{array}$ & $\begin{array}{c}\text { Standard Error } \\
(\text { STERR })\end{array}$ & $\begin{array}{c}\text { T Statistics } \\
(|\mathrm{O} / \mathrm{STERR}|)\end{array}$ \\
\hline FEP -> DSP & 0.279344 & 0.303015 & 0.068768 & 0.068768 & 4.062092 \\
FEP -> KKP & 0.213992 & 0.216328 & 0.073924 & 0.073924 & 2.894768 \\
FIP -> DSP & 0.313500 & 0.344286 & 0.067474 & 0.067474 & 4.646216 \\
FIP -> KKP & 0.229515 & 0.250282 & 0.074386 & 0.074386 & 3,085480 \\
KKP -> DSP & 0.058137 & 0.081564 & 0.095215 & 0.095215 & 0.610588 \\
\hline
\end{tabular}

Furthermore, the mediation test was carried out using the sobel test. Briefly the results of the recapitulation are as Table 4.

Table 4. Recapitulation of the company's financial performance mediation test

\begin{tabular}{lccc}
\hline & t-count & t-table & Criteria \\
\hline FEP->DSP & 1.036 & 1.64 & Not qualified \\
FIP->DSP & 1.330 & 1.64 & Not qualified \\
\hline
\end{tabular}

T table with alpha 0.5 , the t-table value is 1.64 . Based on the Table 4 , it can be concluded that the influence of external factors and internal factors on company competitiveness cannot be mediated by the company's financial performance.

Corporate external factors that are reflected by exports (EK) have a significant direct effect on the competitiveness of companies that is reflected by Sales Growth (PP) and Stock Price Volatility (VHS). This means that external factors that are reflected by exports will be able to increase the competitiveness of companies both in terms of sales growth and the company's stock price. This means that when an increase in exports of companies in the consumer goods industry sector will also be able to increase sales growth and stock prices of companies in the consumer goods industry sector on the IDX.

The findings of this study support the research of Juma (2014) who found a positive relationship between company external factors and the competitiveness of real estate companies. But it does not support the research of Khan, et., Al., (2012) and Prempeh (2016) who found that the company's external factors reflected by the interest rate and inflation did not significantly influence the return of KSE 100 index shares as a proxy for company competitiveness.

The company's external factors that are reflected by exports (EK) have a significant effect on the company's financial performance reflected by ROA, ROE and ROS. The three ratios are the company's profitability ratio. Thus increasing exports will increase company profitability.

The findings of this study support the research of He et al (2017) and ObengKrampah (2018) who found that the interest rate and inflation as a proxy for external 
factors of the company have a significant influence on the company's financial performance. Whereas the Egbunike \& Okerekeoti (2018) studies were not supported due to different significance results. The difference in the results of this study with previous research lies in the difference in the proxy or indicator of the company's external factor variables. In this study the external factor indicator is export. Means that in the sample company research period, the effect of export volume greatly affects the company's financial performance.

In this study the company's external factors significantly influence the competitiveness of the company, but after mediating through financial performance, the company's external factors do not significantly influence the competitiveness variable, this can happen because it is caused by the direct role of external factors that are so large on competitiveness, while in this study the possibility of financial performance represented by indicators of ROA, ROE and ROS does not play a maximum role in the competitiveness of companies in the object in this study. Or in other words, an increase in exports only affects competitiveness but an increase in exports cannot be mediated by profitability to increase competitiveness.

Internal company factors that are reflected by the number of directors (JD), Number of Employees (JP) and company size (UK) have a significant influence on the competitiveness of the company reflected by Growth Growth (PP) and Stock Price Volatility (VHS). This means an increase in the number of directors (JD), the Number of Employees (JP) and the size of the company (UK) is able to increase the Sales Growth (PP) and Stock Price Volatility (VHS).

The findings of this study support the research of Aloui \& Jarboui (2017) investigating the causal relationship between stock return volatility, independent directors, and control variables in the simultaneous equation panel data model of 89 Korean companies during the 2006-2012 period. Empirical results show that the proportion of outside directors destabilizes stock price volatility. This result is statistically significant and strong in a wide range of model specifications. Preliminary test results are consistent with signaling theory (Spence, 1974), which is more important when an investor operates in a particular investment environment, such as in Korea after the 1997 Asian Financial Crisis. Furthermore, the results of the study show that independent directors stabilize stock returns.

Research by Békés, Horváth \& Sápi (2016) states that competitiveness refers to the fact that a company outperforms 'competitors' in terms of size (workers, output, income) and profitability thanks to everything that affects the perceived quality of the company's products and cost effectiveness in supply them. The company's competitiveness boils down to its own ability to produce more added value than given the amount of input, that is, from the total productivity factor (TFP) as measured by the number of employees, directors as well as increasing the scale or size of the company.

Internal company factors that are reflected by the number of directors (JD), Number of Employees (JP) and company size (UK) have a significant influence on the company's financial performance reflected by ROA, ROE and ROS. This means that an increase in the number of directors (JD), Number of Employees (JP) and company size (UK) can increase company profitability.

The findings of this study are in line with the results of research by Bonn, Yoshikawa \& Phan (2004) who found that the size (number) and age of the board of directors were negatively associated with Japanese company performance. Likewise, the research by Wang, Senorate, Rafic (2015) concluded that there is an influence of the 
company's internal factors on the company's financial performance. But it does not support Wu's research (2009) which found no significant relationship between the proportion of independent directors on the board and company performance.

Internal factors significantly influence the competitiveness of companies, but if through mediation of financial performance in this study indicate that internal factors have no effect on the competitiveness of companies. This shows that investors look at the company's internal conditions and do not see the company's financial performance conditions.

The results of this study conclude that the financial performance of companies proxied by ROA, ROE and ROS does not significantly influence the company's competitiveness reflected by Sales Growth and Stock Price Volatility. This means that investors do not see the company's competitiveness as a result of the company's financial performance.

The findings of this study do not support the research of Zanotti, Reyes \& Fernandez (2018) which shows that competitiveness is significantly related to corporate financial performance, but not with operational performance and also Anwaar (2016) research shows that profit margins net, return on assets has a significant positive effect on stock returns while earnings per share has a significant negative impact on stock returns. Meanwhile, the results of Teeratansirikool et al (2013) research stated that the company's financial performance had an influence on the competitiveness of the company itself in the market.

\section{CONCLUSIONS AND RECOMMENDATIONS}

\section{Conclusions}

The external factors of the company have a direct and significant influence on the competitiveness of the company and the company's financial performance. However, the company's external factors do not have a significant influence on the company's competitiveness by mediating the company's financial performance. The company's internal factors have a significant direct effect on the company's competitiveness and financial performance. However, the company's internal factors do not have a significant effect on the company's competitiveness by mediating the company's financial performance.

The company's financial performance does not have a significant direct effect on the company's competitiveness. Thus, it can be concluded that external and internal factors have a positive and significant influence on competitiveness and financial performance, however, the company's financial performance is unable to mediate the influence of external and internal factors on the company's competitiveness.

\section{Recommendations}

Referring to the results of the study which concluded that the company's external factors and the company's financial performance had a significant influence on the company's competitiveness, for issuers in the consumer goods industry group to consider giving more attention to their export activities and asset utilization and increased sales. By providing increased export activity and asset utilization and increasing sales, it will increase the company's competitiveness.

For further researchers, it can examine the export capacity and export destinations of companies in the Consumer Goods Industry Sector and can examine the ideal board size of companies as a contribution to agency theory. 


\section{REFERENCES}

Aloui, M. \& Jarboui, A. (2017). The effects of corporate governance on the stock return volatility: During the financial crisis. International Journal of Law and Management, 60(2), 478 - 495

Anwaar, M. (2016). Impact of Firms' Performance on Stock Returns (Evidence from Listed Companies of FTSE-100 Index London, UK). Global Journal of Management and Business Research,16(1), 30 - 39

Békés, G., Horváth, A. \& Sápi, Z. (2016). Flood Risk and Housing Prices: Evidence from Hungary. IEHAS Discussion Papers. Institute of Economics, Centre for Economic and Regional Studies, Hungarian Academy of Sciences

Bonn, I., Yoshikawa, T. \& Phan, P.H. (2004). Effects of Board Structure on Firm Performance: A Comparison Between Japan and Australia. Asian Business \& Management, 3, 105-125

Egbunike, C.F. \&. Okerekeoti, C.U. (2018). Macroeconomic factors, firm characteristics and financial performance, A study of selected quoted manufacturing firms in Nigeria. Asian Journal of Accounting Research, 3(2), 142-168

Obeng-Krampah, D.K. (2018). The Impact Of Macroeconomic Factors On Firm Performance, [Master's Thesis] The University Of Ghana

Ghozali, I. (2008). Structural Equation Modeling Metode Alternatif dengan Partial Least Square. Semarang: BP-Undip.

Hamel, G \& Praland, C K. (1995). Kompetisi Masa Depan. Jakarta : Bina Rupa Aksara He, Zhen-Xia., Shen, Wen-Xing., Li, Qin-bin., Xu, Shi-Chun., Zaho, Bin., Long, \& RuYin. (2018). Investigating external and internal pressures on corporate environmental behavior in papermaking enterprises of China. Journal of Cleaner Production, 172. 1193 - 1211

Hsiao, Kuo-Lun., Lin, J.C., Xiang-Ying W., His-Peng Lu., \& Hueiju Yu. (2010). Antecedents and Consequences of Trust in Online Product Recommendations. Online Information Review, 33(6), 935-953.

Juma, M. (2014). The Effect Of Macro-Economic Variables On Growth In Real Estate Investment In Kenya, [Master's Thesis]. School Of Business, University Of Nairobi

Khan, Z., Khan, S., Rukh, L. \& Imdadullah. (2012). Impact of Interest Rate, Exchange Rate and Inflation on Stock Returns Of Kse 100 Index. Int.J.Eco.Res, 3(5), 142155 ,

Liang, Yan-Qing., Zhang, Shu-Lin., \& Cui, Yi. (2015). Market Profitability Factors Exploration after the Stock Holding Event of Listed Companies Executives Evidence from China's Stock Market. International conference on management engineering and management innovation (ICMEMI), January 2015.

Morgan, R.M. \& Hunt, S.D. (2004). The CommitmentTrust Theory of Relationship Marketing. Journal of Marketing, 58 (3), 20.

Porter, M. (1980). Competitive Strategy, Techniques for Analyzing Industries and Competitors. New York: The Free Press.

Porter, M. (2008). Strategi Bersaing (Competitive Strategy) Tangerang: Karisma Publishing Group.

Prempeh. (2016). Macroeconomic Variables and Stock Price Volatility in Ghana Munich Personal RePEc Archive, Available at https://mpra.ub.uni-muenchen.de/70545/ MPRA Paper No. 70545

Rivera, J. M., Muñoz, M. J., \& Moneva, J. M. (2017). Revisiting the Relationship Between Corporate Stakeholder Commitment And Social And Financial 
Performance. Sustainable Development, 25(6), 482 - 494

Saedi, P., Sofian S., Rasid, S.Z.A, Saeid, S.P. (2012). The Role of Chief Risk Officer in Adoption and Implementation of Enterprise Risk Management. International Research Journal of Finance and Economics, 88, 118-123.

Sheikh, N. A., Wang, Z., \& Khan, S. (2013). The Impact of Internal Attributes of Corporate Governance on Firm Performance: Evidance From Pakistan. International Journal of Commerce and Management, 23(1), 38-55.

Solimun. (2011). Analisis Variabel moderasi dan Mediasi. Malang: Program Studi Statistika FMIPA Universitas Brawijaya.

Spence, M. (1973). Job Market Signaling. The Quarterly Journal of Economics, 87(3), 355-374.

Teeratansirikool, L., Siengthai, S. Badir, Y., \& Charoenngam, C. (2013). Competitive Strategies and Firms Performance: The Mediating Role of Performance Measurement. International Journal of Productivity and Performance Management, 63(1\&2), 168 - 184

Wu, Wei. (2009). Board Composition And Firm Performance: A Quantitative Study On Chinese Listed Companies. [Master's Thesis] Umea School of Business

Zhaohua, Deng., Yaobin, Lu., Kwok, Kee.Wei., \& Jinlong, Zhang. (2010). Understanding Customer Satisfaction and Loyalty: An Empirical Study of Mobile Instant Messages in China. International Journal of Information Management, 30(4), 289300 . 